\title{
DESCRIPTION OF THE PREPARATORY STAGES OF SATYRUS CHARON, EDW.
}

BY W. H. EDWARDS, COALBURGH, W. VA.

EGG.-Conoidal, somewhat rounded at base ; truncated, nearly flat, a very little convex, at top ; the sides a little convex, and marked by about twenty-two sharp vertical ridges, which start from edge of base and end at rim of summit, the spaces between these ridges deeply and roundly excavated; the summit is covered with shallow cells, irregularly five and six-sided, in four rows, not concentric, but somewhat spiral, about a central rosette of rhomboids. Very like the egg of Alope, but there are a greater number of flutings on sides. Color lemon-yellow. Duration of this stage about 12 days.

Young LaRva. - Length .I inch; the anterior segments thickest, tapering from 3 or 4 to $\mathrm{I} 3$, at the extremity nearly square, with a projecting point at either side; armed with long white processes or bristles, arranged as follows : on either side, a sub-dorsal row, a second on mid-side, and a third along base; also two demi-rows confined to $2,3,4$, one of them between the two upper rows, the other between the second and third rows ; the sub-dorsal has one bristle each on $2,3,4$, bent forward, 2 each from 5 to $\mathrm{I} 2$, I on $\mathrm{I} 3$, besides another proceeding from the terminal point, all bent back; the demi and lateral rows have one to each segment, all bent forward, except those on I2, $\mathbf{3} 3$; the lower row has two to each segment, those on 2 bent forward slightly, all the rest back; these bristles are thick at base and taper a little to a blunt point, and under a high power are seen to be rough with the stubs of branching spurs; there are also over pro- and anal legs two shorter bristles to each; in most of these bristles the bend is close to base, giving them the appearance of so many hooks; and they spring from rather prominent tubercles; color of body pinkish-yellow, with red-brown longitudinal lines, one mid-dorsal, two finer ones close together on mid-side, and another heavier than the last just over spiracles; there is also a less distinct and broken line along base ; legs and pro-legs color of body; head one-half broader than 2, subglobose, narrowing upwards, the top a little depressed; color yellowbrown, specked thickly with red-brown; a few white bristles over surface, like those on body and rising from dark brown tubercles, all bent down; ocelli brown, except the largest, which is emerald-green. 
About eight days after beginning to feed the larva changed color, becoming pale green, the lines as before, head as before. From end of hibernation to first moult 21 to $3^{8}$ days, the larvæ being on grass in a warm room.

After First Moult.-Length at 24 hours after the moult, . 5 inch; tapering from anterior segments to $\mathrm{I} 3$ both dorsally and laterally, the last ones a little arched; 13 ends in two conical tails, one at either side, the space between roundly excavated; body covered with rough tuberculations, from which come short stiff processes, not tapering, but small at base, and thick at end and rounded, varying in size and somewhat in length; rough also like the bristles at first stage; except on 2 , where these are turned forward, all are bent back and flattened to the body, which gives a downy coating to whole surface ; color green ; a pale brown mid-dorsal line, two such on middle of side and another over spiracles; feet green, whitish at ends, pro-legs green; head a little broader than $\mathbf{2}$, sub-globose, bright green, pitted with darker green, rough with white tubercles, each of which gives a process like those on body, and bent down; ocelli emerald. Duration of this stage 15 to 20 days.

After Second Moult.-Length at 24 hours, .3 inch; same shape; color either yellow-green or a bluish sage-green; covered with bent processes as before; the lines as before, but green instead of brown ; along base a yellow stripe; head as before. Duration of this stage I 2 to I8 days.

After Third Moult.-Length at 20 hours, .4 inch ; color yellow-green ; tails reddish; the mid-dorsal stripe distinct, the three side lines not well defined; the basal ridge yellow; there is also now a sub-dorsal line or narrow stripe of pale yellow. Duration of this stage $I_{5}$ to 20 days.

After Fourth Moult. - Length at I 8 hours .54 inch; closely as in last previous stage ; 5 days later was fully grown.

Mature Larva.-Length .94 inch, greatest breadth .I2 inch; cylindrical, tapering from middle to end both on dorsum and sides, rather stout in middle, but not obese, the anterior segments even; ends in two sharp conical divergent tails; each segment creased six times, and on the flattened ridges so caused are numerous fine yellowish tubercles, each of which sends out a short, slender, white process, more or less pressed to the surface; color yellow-green over dorsum to sub-dorsal band, from that to base more green, less yellow; the tails pale red, on outer sides 
yellow; the sub-dorsal band nearly as wide as basal, and same shade of yellow; the dorsal stripe is dark green, and is edged on either side narrowly by yellow; feet and legs green; head sub-globose, broad at base, narrowing upwards, a little depressed at top ; roughly tuberculated, the tubercles in vertical rows, conical, each with white hair ; color bright green ; the ocelli brown, except the largest, which is emerald. Duration of this stage 20 days at the least.

Chrysalis.-Length, male .4 inch, female .5 to .54 inch; breadth across mesonotum, male .I6, female .I7; across abdomen, male .I7, female .r 8 inch; cylindrical, abdomen conical; head case short, narrow at top and a little convex, the sides excavated; mesonotum prominent, roundly carinated, the sides somewhat convex, followed by a shallow depression; color pale yellow-green, the dorsal side throughout, and the ventral side of abdomen, thickly dotted and mottled with whitish; three whitish stripes along dorsum, one in middle, the others sub-dorsal, and running from end to end; on the wing cases are three streaks of darker green, the longest in mid-wing and reaching hind margin, the others short and stopping before margin; there are also some small patches same green ; wing cases next base, the top of head case and keel of mesonotum lined with white.

Another example was wholly whitish-green, no dark streaks on wing cases and no dorsal bands.

Others were greenish-black, finely dotted gray; the three dorsal stripes gray; the wings black and gray, about equally, running in streaks with the nervules.

Another was of a dull brown, with no tinge of green, marked like the last described, but the light parts were of a pinkish-white; on the wings were three deep black streaks, corresponding to the green ones before mentioned. Duration of this stage I I to I 2 days,

This pretty little Satyrus was first made known by Mr. T. L. Mead, who took it in Colorado in I87 I. It was described by me in Trans. Am. Ent. Soc., iv., p. 69, I872, and appended was a note as follows: "This species was first met near the Twin Lakes, in Upper Arkansas Valley, elevation 8,000 feet, in July, $187 \mathrm{I}$. It flew near the ground, frequently alighting on the sage-brush, and seemed much more partial to flowers than was Satyrus (Hipparchia) Ridingsii, also common in that vicinity. By the latter part of July it was abundant throughout the entire Park and 
mountain country, and so continued till September." In Mr. Mead's Report on the Lepidoptera taken by the Wheeler Expeditions, 1875, it was farther said of Charon: "It was found both in South and Middle Parks, though not so abundantly as in the Arkansas Valley. In August, females were obtained and inclosed with grass; several eggs were laid; they are whitish and very similar to those of Nephele." I do not know that another line has been published on the habits of this butterfly than what Mr. Mead wrote or authorized as above, although the species has been taken in many localities from New Mexico to Montana, and even in British America, as appears by Captain Geddes' list. Mr. Morrison also took it in Nevada.

I received 20 eggs of Charon from Mr. H. W. Nash, then at Rosita, Colorado, 4th August, 1884 ; on the Ioth August, 23 more, and many others on I4th Aug.; sent through the mail, in turned wooden boxes, the eggs all obtained by confining females in bags over grass. They came in perfect order, and began to hatch, the Ist lot, roth Aug., the 2 nd lot, I 7 th. The larvæ were remarkably like those of Alope, same shape, color, longitudinal bands and processes, and the latter were bent like fish-hooks, just as in Alope. I had larvæ of Hipparchia Ridingsii hatching at same time, and the difference between them and the larvæ of Charon at this stage was striking. It was generic. The same resemblance to Alope runs through the whole history of Charon, egg, all the larval stages, and the chrysalis, except that in color this last is variable as to coloration in Charon, and not in Alope.

The larvæ devoured the egg shells more or less completely, but eat no grass, and settled themselves for a winter's sleep. I left them for several weeks in the cellar, in paper pill boxes. On roth October, they were sent to Clifton Springs, New York, and placed in the "cooler" of the Sanitarium there, temp. all the year $40^{\circ} \mathrm{Far}$. On 7 th $\mathrm{March}, \mathrm{r} 885$, I received the larvæ again; nearly all were alive, and they were placed on a sod of grass set in flower pot, and covered by a glass lamp chimney. On 8th, several were feeding. The first larva passed ist moult $29^{\text {th }}$ March, but several were ready to pass this moult for about a week had the weather been pleasant, instead of cold, cloudy and stormy, much of the time. Two more passed the moult 2 nd April. The last one of $I_{5}$ larvæ passed Ist moult $r_{5}$ th April ; so that between the first and last was an interval of 77 days. 
The second moult began on 9th April, and the last one of ro larvæ passed same 2 ist April, a difference of 12 days.

The third moult began 2 Ist April, and the last of 8 larvæ passed same 7 th May, a difference of $I_{5}$ days.

The fourth moult began $3^{\text {rd }}$ May, and the last of 9 larvæ passed same 6th June, a difference of 34 days.

The first chrysalis formed zoth May, and the last larva was mature Ioth June, and would have pupated about $\mathrm{I}_{5}$ th, had I not put it in alcohol. The difference would have been about 26 days in pupating.

The first imago out of chrysalis was on and June, the pupa period being from $1 \mathrm{I}$ to 12 days.

So that, supposing larvae to behave in natural condition as these in confinement, fresh butterflies from same brood would be coming out daily for several weeks. And so undoubtedly they do, as is the case with Alope.

\section{LARVA OF COELODASYS MUSTELINA, PACK.}

BY G. H. FRENCH, CARBONDALE, ILL.

Length .80 of an inch. Head oblique, narrow, slightly bilobed, about one-fourth of the head above the height of joint 2 ; body nearly cylindrical ; on joint 5 a nearly conical projection about two-thirds as high as the depth of the body, bifid at the top, each part tipped with a hair ; on joint 9 is a slight elevation, and a more prominent one on joint $\mathrm{I} 2$. When at rest the posterior part of the body is raised, making these elevations appear more prominent. In color, the head, joint $\mathbf{2}$, and the dorsum of joints 3 and 4 to the top of the tubercle on joint 5 , is dark brownish purple mottled with gray, the sides being lighter than the front of the head and the dorsum, the latter narrow posteriorly; the sides of joints 3 and 4 are bright green with a few fine purple dots and a pale dorsal edging; the sides of the body back of joint 4 are a series of fine, close, crenate purplish red lines or mottlings on a grayish yellow ground color, more yellow above, giving the sides something of an orange appearance ; the dorsum of joints 5 to 8 is more of a grayish color from the ground color being paler and the mottlings finer and more of a purple shade; a darker patch on the dorsum of joint 8 , this color extending 